\title{
Local regulation of the coronary circulation in health and disease: role of nitric oxide and endothelin
}

\author{
T. F. LÜSCHER, R. R. WENZEL AND G. NOLL \\ Cardiology, Cardiovascular Research, University Hospital, Bern, Switzerland
}

KEY WORDS: Coronary artery disease, endothelial cells, nitric oxide.

Coronary artery disease is the leading cause of morbidity and mortality in western countries. Its pathogenesis is unknown, but involves enhanced vasoconstriction, increased interaction of platelets and monocytes with the vessel wall, as well as proliferation, migration and extracellular matrix formation of vascular smooth muscle. The endothelium lies in a strategic anatomical position between circulating blood and vascular smooth muscle cells. This supports the concept that dysfunction of these cells significantly contributes to coronary artery disease. Besides other mediators, endothelial cells are a source of nitric oxide and endothelin.

Nitric oxide is a vasodilator, an inhibitor of both platelet function and proliferation and migration of vascular smooth muscle. Endothelin is a potent vasoconstrictor that facilitates proliferation.

Under pathological conditions, in particular the presence of cardiovascular risk factors, endothelial dysfunction occurs and is a major contributor to the increase in platelet vessel wall interaction, vasoconstriction and proliferation in the coronary system. Endothelium-dependent vasodilation is usually reduced and endothelium-dependent constrictor responses, as well as endothelin production, are augmented. Hence, endothelial cells are important targets and mediators of coronary artery disease.

\begin{abstract}
Introduction
Coronary artery disease is an important cause of morbidity and mortality in western countries. The disease is only partially understood, but involves increased vasoconstrictor responses, enhanced interaction of circulating blood cells with the blood vessel wall and proliferation and migration of vascular smooth muscle ${ }^{[1]}$. These events impair coronary blood flow during exercise and/or under resting conditions,

Due to their strategic anatomical position, endothelial cells can regulate blood cells as well as vascular smooth muscle (see ${ }^{[1]}$ ). Endothelium-derived factors modify platelet function as well as the contractile and proliferative state of vascular smooth muscle. Nitric oxide and prostacyclin are vasodilators and inhibitors of platelet function. In addition, endothelial cells produce vasoconstrictors such as prostaglandin $\mathrm{A}_{2}$ and thromboxane $\mathrm{A}_{2}$ as well as endothelin-1. Furthermore, endothelial cells are a source of growth promoters and inhibitors.
\end{abstract}

\section{Nitric oxide and vascular regulation}

Endothelium-dependent vasodilation is mediated by nitric oxide (NO) (Fig. $1^{[2-5]}$ ). Nitric oxide is formed from L-arginine ${ }^{[2]}$ via the constitutive form of NO synthase ${ }^{[6]}$ and

Supported by grants of the Swiss National Research Foundation (No. 32 32541.91, 32-35591.92), the Sandoz Foundation and an educational grant by Swiss Mobiliar Insurance. Dr R. R. Wenzel is supported by a grant of the German Research Association (Deutsche Forschungsgemeinschaft, No. WE 1772/1.1)

Correspondence: Thomas F. Lüscher. MD. Professor of Medicine. Cardiology. University Hospital. Inselspital. CH-3010 Bern, Switzerland. causes relaxation via activation of guanylyl cyclase in vascular smooth muscle.

In porcine coronary arteries, endothelium-dependent relaxations to serotonin are prevented by inhibitors of NO formation, while the relaxations to bradykinin are only partially inhibited ${ }^{[7]}$. Pertussis toxin, which ADPribolysates $G_{i}$ proteins, has no effects on bradykinininduced relaxations, but prevents those to serotonin ${ }^{[7.8]}$. Endothelial 5-HT 1 serotonergic receptors (as well as $\alpha_{2}$ receptors; ${ }^{[8]}$ ) are linked to $G_{1}$ proteins and activate the $L$ arginine NO pathway. In contrast, the bradykinin receptor is not linked to a pertussis toxin sensitive pathway and NO only in part contributes to its relaxations.

NO is formed under basal conditions. Inhibition of NO formation by L-NMMA or endothelium removal causes endothelium-dependent contractions ${ }^{[9.10]}$, increases vasoconstrictor responses of coronary arteries ${ }^{[4]}$ and increases arterial blood pressure in vivo ${ }^{[1]}$. Furthermore, shear stress increases NO formation ${ }^{[12]}$ and in turn causes flowdependent vasodilation ${ }^{[13-15]}$.

\section{Nitric oxide and platelet-vessel-wall interaction}

The fact that platelets remain inactivated despite high shear stress in the arterial circulation may be due to the continuous release of inhibitors of platelet function from endothelial cells such as $\mathrm{NO}$ and prostacyclin (Fig. $2^{[1]}$ ). Both mediators prevent platelet adhesion and aggregation $^{[16-19]}$.

Activated platelets release serotonin, thromboxane $A_{2}$, ATP and ADP, platelet-derived growth factor and transforming growth factor beta- 1 . Several of these mediators 


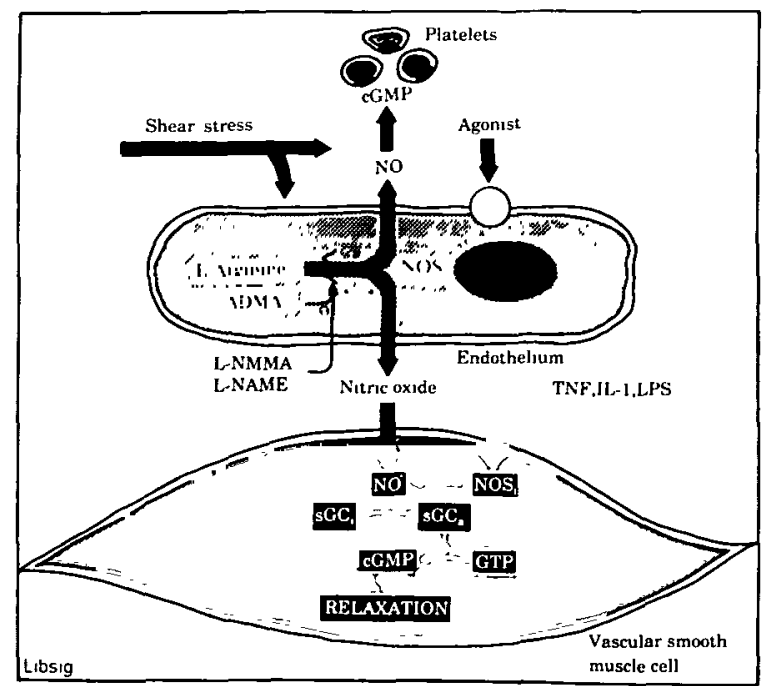

Figure I The endothelium produces nitric oxide (NO), which causes relaxation. $\mathrm{O}=$ receptors; $\mathrm{cGMP}=$ cyclic guanosine monophosphate: GTP = guanosine triphosphate; NOS $_{\mathbf{c}}=$ constitutive nitric oxide synthase; NOS $_{1}=$ inducible nitric oxide synthase; $\mathrm{ADMA}=$ asymmetric dimethyl arginine; L-NMMA = L-monomethylarginine; $\quad$ L-NAME = L-nitro-arginine methylester; $\mathbf{s G C}_{\mathrm{a}}=$ inactive/activated soluble guanosine cyclase; $\mathrm{TNF}=$ tumour necrosis factor; $\mathrm{IL}-1$ = interleukin-1; LPS = lipopolysaccharide.

interact with endothelial receptors (Fig. $2^{(1)}$ ). In addition, platelets possess an L-arginine-NO-pathway which blunts aggregatory stimuli ${ }^{[18]}$.

In human coronary and internal mammary arteries, aggregating platelets cause endothelium-dependent relaxations via $\mathrm{NO}^{[2021]}$. ADP and serotonin are important mediators ${ }^{[22]}$.

In contrast to normal arteries, arteries devoid of endo-

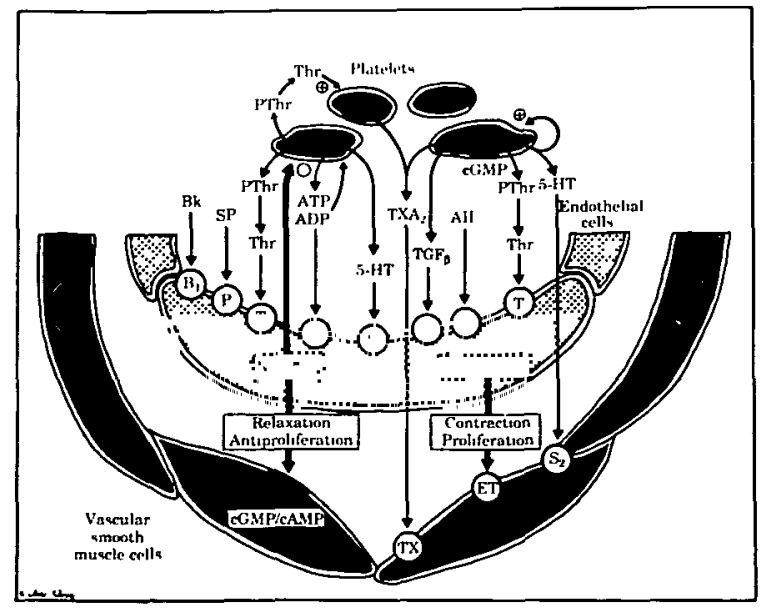

Figure 2 Activated platelets release numerous factors which can interact with receptors on the endothelium and vascular smooth muscle. $\mathrm{O}=$ receptors: $\mathrm{PThr}=$ prothrombin: $\mathrm{Thr}=$ thrombin: $\mathrm{Bk}$ $=$ bradykinin: $5-\mathrm{HT}=$ serotonin; $\mathrm{TGF}_{\beta}=$ transforming growth factor $\beta: \mathrm{TXA}_{2}=$ tromboxan $\mathrm{A}_{2}: \mathrm{NO}=$ nitric oxide: $\mathrm{PGl}_{2}=$ prostacyclin; cGMP = cyclic guanosine monophosphate; ATP/ADP = adenosine-tri(di)phosphate: $\mathrm{AII}=$ angiotensin II . (Modified from ${ }^{[1]}$.) thelial cells or with dysfunctional endothelium contract to aggregating platelets ${ }^{[21]}$ due to serotonin and thromboxane $\mathrm{A}_{2}{ }^{[21.22]}$.

Where platelets are stimulated, thrombin is formed. Thrombin is a potent activator of platelets ${ }^{[19]}$, but also has endothelial effects. Its receptor has been cloned ${ }^{[23-25]}$. Thrombin causes endothelium-dependent relaxations in human coronary and internal mammary artery which are inhibited by indomethacin and L-nitroarginine methylesther (Fig. 3; L-NAME ${ }^{26.27]}$ ). Hence both NO and prostacyclin contribute (Fig. 2). These effects counteract the direct activating effects of thrombin in platelets. In the absence of endothelium, thrombin causes a potentiation of plateletinduced contractions via release of thromboxane $\mathrm{A}_{2}{ }^{[26]}$.

\section{Endothelium-dependent contraction}

The endothelium produces contracting factors via cyclooxygenase (i.e. prostaglandin $\mathrm{H}_{2}$ and thromboxane $\mathrm{A}_{2}{ }^{[4,28]}$ and the peptide endothelin- ${ }^{[28-34]}$ ). While endothelin-1, the primary product of endothelial cells, is a potent activator of $\mathrm{ET}_{\mathrm{A}}$ receptors which are primarily expressed on vascular smooth muscle cells ${ }^{[35]}$, endothelin-3 is much less potent at this receptor. In contrast, $E_{\mathrm{B}}$ receptors, which are expressed on endothelium and smooth muscle, bind endothelin-1 and endothelin-3 equally well (Fig. $4^{[36]}$ ).

$\mathrm{ET}_{\mathrm{A}}$ receptors are linked to phospholipase $\mathrm{C}$ which leads to the formation of inositoltrisphosphate as well as diacylglycerol $^{[37,38]}$. These second messengers lead to the intracellular release of $\mathrm{Ca}^{2+[39]}$ and activation of protein kinase $\mathrm{C}$. Endothelin receptors are linked via a $G_{1}$ protein to voltageoperated $\mathrm{Ca}^{2+}$ channels ${ }^{[40]}$. $\mathrm{ET}_{\mathrm{A}}$ and $\mathrm{ET}_{\mathrm{B}}$ receptors on smooth muscle contribute to the contractile proliferative effects of endothelin (see $e^{(41)}$ ).

Endothelial receptors are of $\mathrm{ET}_{\mathrm{B}}$ type and linked to NO and prostacyclin ${ }^{[42-44]}$ mediating initial transient vasodilation which occurs with intraluminal infusion of endothelin ${ }^{[34.35]}$.

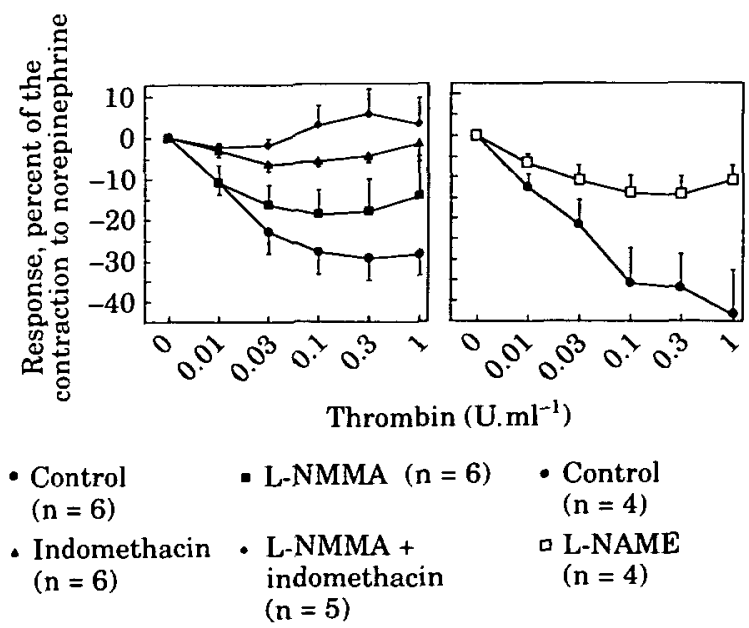

Figure 3 Thrombin-induced relaxation in the human internal mammary artery. Indomethacin and L-NMMA (left panel) and L-NAME (right panel) inhibit thrombin-induced vasodilation, suggesting that thrombin acts through release of both NO and prostacyclin. ( ${ }^{26]}$, with permission of the American Heart Association.) 


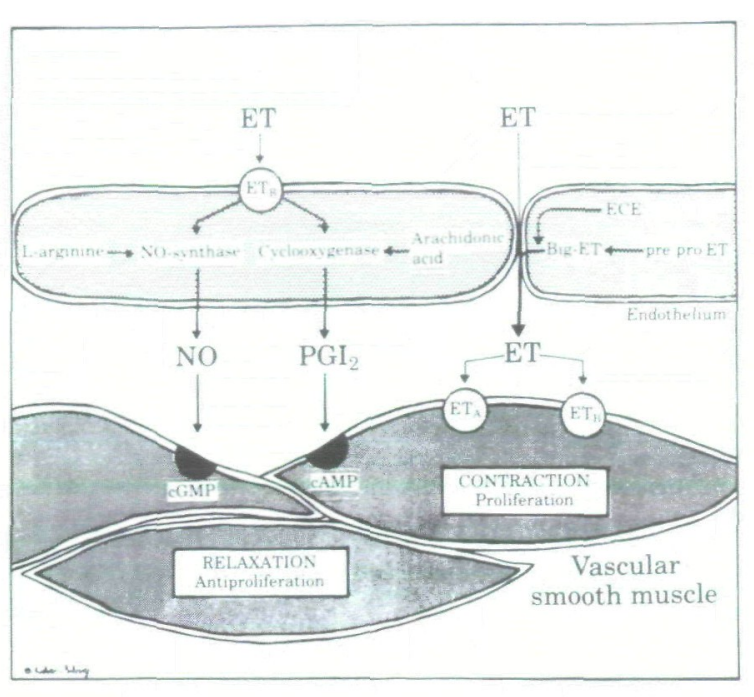

Figure 4 Endothelın (ET) is mainly released abluminally to interact with $E T_{A}$ and $E T_{B}$ receptors on vascular smooth muscle. Activation of $E T_{B}$ receptors on the endothelium causes vasodilation. $\mathrm{cAMP} / \mathrm{cGMP}=$ cyclic adenosine and/or guanosine monophosphate: $\mathrm{NO}=$ nitric oxide: $\mathrm{O}=$ receptors: $\mathrm{PGI}_{2}=$ prostacyclin: $\mathrm{ECE}$ $=$ endothelin converting enzyme. (From ${ }^{[120]}$, with permission)

Endothelin production is stimulated by hypoxia (including that occurring at high altitude ${ }^{|46.47|}$, mechanical forces, as well as thrombin, interleukin-1, arginine vasopressin and angiotensin II ${ }^{[28.32 .34 .48]}$.

Plasma endothelin levels are very low ${ }^{[49]}$. This may be related to the fact that most of the peptide is released abluminally ${ }^{[50]}$ and to inhibitory mechanisms of production ${ }^{[32,51-54]}$. Three inhibitory mechanisms have been delineated, i.e. a cGMP-dependent pathway activated by $\mathrm{NO}^{[32.5354]}$ and atrial inatriuretic peptide ${ }^{[53]}$, a cAMP pathway activated by prostaglandins and a putative inhibitory factor produced by smooth muscle cells ${ }^{[52]}$.

Endothelin antagonists inhibit the effects of endothelin [55-71]. Some inhibit $E T_{A}$ receptors and others $E T_{A}$ and $E T_{B}$ receptors. With these drugs it could be shown that $E T_{B}$ receptors on vascular smooth muscle cells also contribute to the contractile and potentially proliferative effects of endothelin. Indeed, in contrast to $\mathrm{ET}_{\mathrm{A}}$ receptor antagonists, combined $\mathrm{ET}_{\mathrm{A}}$ and $\mathrm{ET}_{\mathrm{B}}$ receptor antagonists in vitro are able to fully inhibit endothelin-induced contractions in a competitive manner in human mammary arteries ${ }^{[41.72 \mid}$. On the other hand, in the human skin microcirculation endothelin activates mainly $\mathrm{ET}_{\mathrm{A}}$ receptors, as both the selective $E_{\mathrm{A}}$ antagonist and the $\mathrm{ET}_{\mathrm{A}} / \mathrm{ET}_{\mathrm{B}}$ antagonist inhibit the effects of endothelin ${ }^{[73]}$. Endothelin antagonists will help to characterize the distribution of endothelin receptors and their pathophysiological importance $e^{[74]}$.

Although in atherosclerosis, myocardial infarction, coronary spasm, pulmonary and possibly arterial hypertension, endothelin plasma levels are elevated ${ }^{[41.75-79]}$, the pathophysiological role of these findings remain controversial. Endothelin receptor antagonists will clarify the role of endothelin in disease. In experimental situations they improve blood flow after acute renal failure and in cerebral vasospasm and decrease blood pressure in sodium-depleted monkeys ${ }^{[80]}$.

\section{Effects of hyperlipidaemia and atherosclerosis}

Endothelial dysfunction can occur due to (1) different expression of endothelial receptors, (2) alteration in signal transduction (in particular $\mathrm{G}$, proteins), (3) alteration in the activity or expression of enzymes such as NO synthase, endothelin converting enzyme. (4) increased breakdown of the factor and/or (5) response of target cells (i.e. platelets and vascular smooth muscle).

Exposure of coronary arteries with low density lipoprotein (LDL) does not cause alterations in endothelial function unless the lipids have been oxidized ${ }^{[81-83]}$. Thus oxidation of LDL alters its biochemical properties, in particular its capability to interfere with the LDL receptor, and allows it to interact with a scavenger receptor ${ }^{[81]}$. This alters endothelial function by (1) interfering with the $G_{i}$ protein of serotonergic and alpha-2 adrenergic receptors $^{[7,8]},(2)$ reducing intracellular mobilization of L-arginine $^{[82]}$ or (3) the activity of NO synthase and/or (4) due to inactivation of $\mathrm{NO}$ by oxidized products ${ }^{[8+1}$. Hence oxidation of $\mathrm{LDL}$ is a crucial ste ${ }^{[8.5]}$; and anti-oxidants such as vitamins $C$ and $E$, and probucol protect the coronary circulation, in particular endothelial cells ${ }^{[86-92]}$. Chronic hyperlipidaemia induces similar changes in endothelial function as does acute exposure of oxidized LDL ${ }^{[93]}$. In atherosclerotic plaques oxidized $\mathrm{LDL}$ is present ${ }^{[85]}$. More recent evidence suggests that in hyperlipidaemia and atherosclerosis NO expression and activity is not reduced (but rather increased) the reduced biological activity of $\mathrm{NO}$ is due to inactivation by superoxide radicals ${ }^{[84]}$.

In contrast to hyperlipidaemia, in atherosclcrosis, not only the response to serotonin, but also that to bradykinin as well as the calcium ionophore A23187 is reduced ${ }^{[20,84,93,94]}$. Studies in the catheterization laboratory showed that infusion of acetylcholine or serotonin causes a paradoxical contraction in patients with coronary artery disease, while they induce vasodilation in patients without coronary artery disease ${ }^{[55}$. Receptor-operated mechanisms activated by acetylcholine or serotonin become dysfunctional early, while flow-dependent stimulation becomes dysfunctional very late ${ }^{[95]}$. Impairment of flow-dependent vasodilation can be demonstrated not only pharmacologically by infusion of a vasodilator distal to the site of angiographic measurements ${ }^{[14.15,95]}$, but also during exercise, when patients with coronary artery disease exhibit a paradoxical vasoconstriction of epicardial coronary $\operatorname{arteries}^{[96]}$.

Abnormal coronary vasomotion in hyperlipidaemia and atherosclerosis is not only due to dysfunction of the L-arginine NO pathway, but also to increased formation of contracting factors. In regenerated endothelial cells a cyclooxygenase-derived contracting factor facilitates contractions to serotonin ${ }^{[97]}$. Increased endothelin levels occur in atherosclerosis, coronary spasm and acute myocardial infarction ${ }^{[76,77,98]}$. Oxidized LDL in atherosclerotic blood vessels stimulates endothelin production ${ }^{[99]}$, as well as hypoxia $^{[47]}$ and thrombin ${ }^{[32]}$. Increased local endothelin 


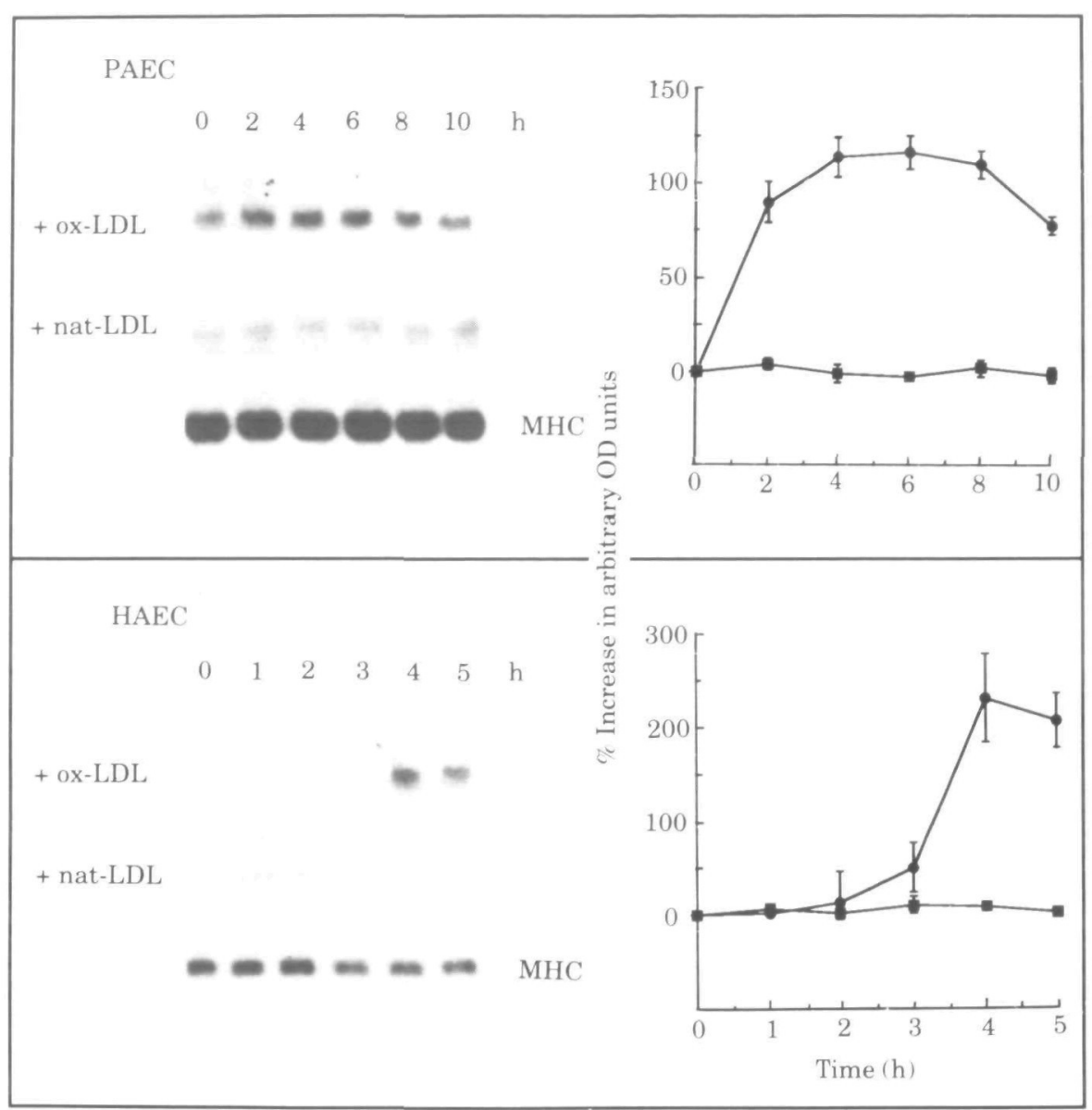

Figure 5 Effect of oxidized (ox-LDL: $\bullet=100 \mu \mathrm{g} \cdot \mathrm{ml}^{-1}$ ) and native (nat-LDL) low-density lipoproteins ( $\square=200 \mu \mathrm{g} \cdot \mathrm{ml}^{-1}$ ) on endothelin messenger RNA expression in cultured porcine (PAEC) and human aortic endothelial cells (HAEC). Only the oxidized form of LDL stimulates endothelin. (From ${ }^{[99]}$, with permission of the American Heart Association.)

production may contribute to vasoconstriction and ischaemia and proliferation ${ }^{[100]}$.

Little is known about the release of growth promoters and stimulators of migration from endothelial cells in hyperlipidaemia and atherosclerosis ${ }^{[101]}$ (Fig. $5^{[99]}$ ). A reduced formation and/or an increased breakdown of NO could facilitate proliferation and migration of vascular smooth muscle ${ }^{[101,102]}$.

\section{Effects of hypertension}

Hypertension is associated with endothelial dysfunction $^{[103]}$ most likely as a consequence of hypertension. It appears that endothelial dysfunction is related to the degree of blood pressure elevation. Normalization of blood pressure-at least in the rat-normalizes endothelium-dependent relaxation ${ }^{[104]}$.

Potential intracellular mechanisms of endothelial dysfunction in hypertension are similar as in hyperlipidaemia and atherosclerosis (see above). In addition, endotheliumderived contracting factors, in particular cyclooxygenase products. are important ${ }^{[28]}$. Endothelial dysfunction in the aorta and cerebral and renal circulation is not related to alterations in the L-arginine NO pathway, but to the release of endothelium-derived cyclooxygenase products = i.e. prostaglandin $\mathrm{H}_{2}{ }^{[105]}$. Coronary arteries of REN-2 transgenic rats exhibit a decreased basal but not stimulated (by acetylcholine) formation of $\mathrm{NO}^{[106]}$.

In large conduit arteries of Dahl salt-sensitive rats, mainly impaired formation of NO is responsible for blunted endothelium-dependent relaxations, although an impaired response of smooth muscle to NO also a contributes ${ }^{[07]}$. Most direct measurements of the activity of NO synthase suggest normal or increased enzyme function $^{[108]}$. Hence, it is possible that similar to experimental atherosclerosis, an increased breakdown of NO occurs.

In hypertensive subjects, most studies were performed in the forearm circulation. Results showed impaired endothelium-dependent vasodilation to acetylcholine, but preserved responses to sodium nitroprusside ${ }^{\mid 5,109-112]}$. However, others were unable to reproduce these findings ${ }^{[13]}$. In contrast, in the coronary circulation of hypertensive subjects, endothelium-dependent vasomotion of epicardial coronary arteries is abnormal ${ }^{[14]}$. The increase in coronary blood flow induced by acetylcholine is also blunted in hypertensive subjects, in particular in the presence of left ventricular hypertrophy ${ }^{[95.115]}$. Hence, in the human, the 


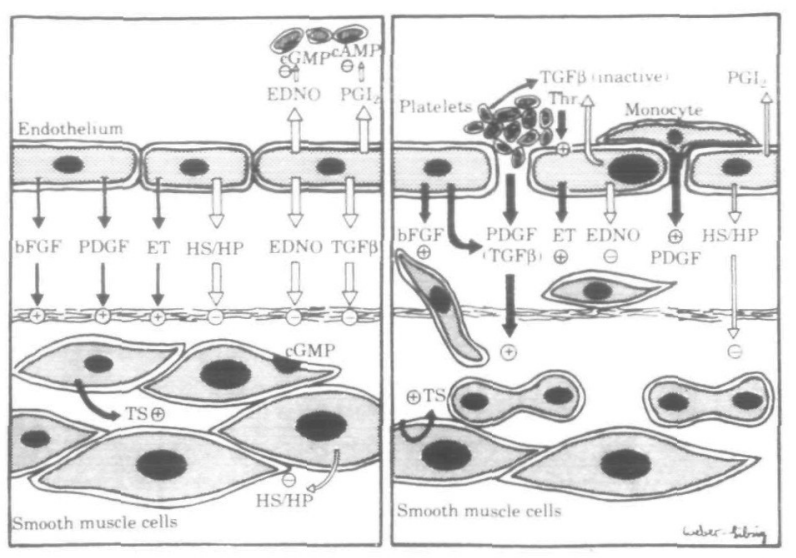

Figure 6 Local vascular mechanisms of proliferation of vascular smooth muscle cells in the blood vessel wall. Platelet, monocytes and endothelial cells release growth promoters (black arrows) and inhibitors (white arrows) which normally keep the blood vessel wall in a quiescent state (left panel). Under pathological conditions such as atherosclerosis, proliferation and migration of vascular smooth muscle cells as well as adhesion of monocytes and platelets occurs. $\mathrm{EDNO}=$ nitric oxide; $\mathrm{PGI}_{2}=$ prostacyclin; PDGF = platelet derived growth factor; $b F G F=$ basic fibroblast growth factor; HS/HP = heparin sulfate/heparin; TS $=$ thrombospondin; $\mathrm{TGF} \beta=$ transforming growth factor $\beta ; \mathrm{ET}=$ endothelin; $\mathrm{Thr}=$ thrombin; $\mathrm{cGMP}=$ cyclic guanosine monophosphate; cAMP $=$ cyclic adenosine monophosphate. $\left(\right.$ From $^{[103]}$, with permission.)

coronary circulation exhibits impaired endothelial function in the presence of hypertension.

The role of endothelin in hypertension is controversial $\left(\operatorname{see}^{[41]}\right)$. Most studies find normal plasma levels. The vascular response to endothelin-1 is paradoxically reduced in experimental hypertension, while the indirect potentiating effects of endothelin are augmented. Hence, the exact role of endothelin in hypertension remains uncertain, but more recent studies using inhibitors of endothelin converting enzyme or receptors suggest that endothelin may contribute to blood pressure elevation ${ }^{[16,117]}$. On the other hand endothelin-2 transgenic rats do not develop high blood pressure inspite of high circulating endothelin-2 levels ${ }^{[18]}$ and 'knock-out' endothelin rats (which lack the endothelin-1 gene) are hypertensive and have marked malformations of the larynx and throat ${ }^{[119]}$. Studies in patients with essential hypertension will reveal whether inhibition of endothelin receptors is associated with a decrease in arterial blood pressure ${ }^{[120]}$.

\section{References}

[1] Lüscher TF, Vanhoutee PM. The endothelium: modulator of cardiovascular function. Boca Raton: CRC Press, 1990.

[2] Palmer RM, Ashton DS, Moncada S. Vascular endothelial cells synthesize nitric oxide from L-arginine. Nature 1988; 333: 664-6.

[3] Palmer RM, Ferrige AG, Moncada S. Nitric oxide release accounts for the biological activity of endothelium-derived relaxing factor. Nature $1987 ; 327: 524-6$.

[4] Yang ZH, von SL, Bauer E, Stulz P, Turina M, Luscher TF. Different activation of the endothelial $L$-arginine and cyclooxygenase pathway in the human internal mammary artery and saphenous vein. Circ Res 1991: 68: 52-60.

[5] Linder L. Kiowski W. Buhler FR. Lüscher TF. Indirect evidence for release of endothelium-derived relaxing factor in human forearm circulation in vivo. Blunted response in essential hypertension. Circulation 1990: 81: 1762-7.

[6] Bredt DS. Hwang PM. Glatt CE. Lowenstein C. Reed RR. Snyder SH. Cloned and expressed nitric oxide synthase structurally resembles cytochrome $\mathrm{P}-450$ reductase. Nature 1991; 351: 714-8.

[7] Richard V, Tanner FC. Tschudi M, Luscher TF. Different activation of L-arginine pathway by bradykinin, serotonin. and clonidine in coronary arteries. Am J Physiol 1990; 259: H1433-H1439.

[8] Flavahan NA, Shimokawa H́, Vanhoutte PM. Pertussis toxin inhibits endothelium-dependent relaxations to certain agonists in porcine coronary arteries. J Physiol 1989; 408: 549-60.

[9] Tschudi M, Richard V, Buhler FR. Luisher TF. Importance of endothelium-derived nitric oxide in porcine coronary resistance arteries. Am J Physiol 1991; 260: H13-20.

[10] Rees DD, Palmer RM, Hodson HF, Moncada S. A specific inhibitor of nitric oxide formation from L-arginine attenuates endothelium-dependent relaxation. $\mathrm{Br} \mathbf{J}$ Pharmacol 1989; 96: 418-24.

[11] Rees DD, Palmer R, Moncada S. Role of endotheliumderived nitric oxide in the regulation of blood pressure. Proc Natl Acad Sci USA 1989; 86: 3375-8.

[12] Rubanyi GM, Romero JC, Vanhoutte PM. Flow-induced release of endothelium-derived relaxing factor. Am J Physiol 1986: 250: H1 145-9.

[13] Pohl U, Holtz J, Busse R, Bassenge R. Crucial role of endothelium in the vasodılator response to increased flow in vivo. Hypertension 1986; 8: 37-44.

[14] Drexler H, Zeiher AM. Wollschlager H, Meinertz T, Just H. Bonzel T. Flow-dependent coronary artery dilatation in humans. Circulation 1989; 80: 466-74.

[15] Cox DA, Vita JA. Treasure CB et al. Atherosclerosis impairs flow-mediated dilation of coronary arteries in humans. Circulation 1989: 80: 458-65.

[16] Macdonald PS, Read MA, Dusting GJ. Synergistic inhibition of platelet aggregation by endothelium-derived relaxing factor and prostacyclin. Thromb Res 1988; 49:437-49.

[17] Radomski MW, Palmer RM, Moncada S. Endogenous nitric oxide inhibits human platelet adhesion to vascular endothelium. Lancet 1987; 2: 1057-8.

[18] Radomski MW, Palmer RM, Moncada S. The anti-aggregating properties of vascular endothelium: interactions between prostacyclin and nitric oxide. Br J Pharmacol 1987; 92: 639-46.

[19] Busse R, Luckhoff A, Bassenge E. Endothelium-derived relaxant factor inhibits platelet activation. Naunyn Schmiedebergs Arch Pharmacol 1987; 336: 566-71.

[20] Förstermann U, Mugge A, Bode SM, Frolich JC. Response of human coronary arteries to aggregating platelets: importance of endothelium-derived relaxing factor and prostanoids. Circ Res 1988; 63: 306-12.

[21] Yang ZH. Stulz P, von SL, Bauer E, Turina M, Luscher TF Different interactions of platelets with arterial and venous coronary bypass vessels. Lancet 1991; 337: 939-43.

[22] Golino P, Piscione F, Willerson JT et al. Divergent effects of serotonin on coronary-artery dimensions and blood flow in patients with coronary atherosclerosis and control patients [see comments]. N Engl J Med 1991; 324: 641-8.

[23] Rasmussen UB, Vouret-Craviari V, Jallat $S$ et al. cDNA cloning and expression of a hamster alpha-thrombin receptor coupled to $\mathrm{Ca} 2+$ mobilization. Febs Lett 1991;288: 123-8.

[24] Vu TK. Wheaton VI, Hung DT. Charo I, Coughlin SR. Domains specifying thrombin-receptor interaction. Nature 1991; 353: 674-7.

[25] Vouret-Craviari V, Van Obberghen-Schilling E, Rasmussen UB, Pavirani A, Lecocq JP. Pouyssegur J. Synthetic alphathrombin receptor peptides activate $G$ protein-coupled signaling pathways but are unable to induce mitogenesis. Mol Biol Cell 1992; 3: 95-102. 
[26] Yang Z, Arnet U, Bauer E et al. Thrombin-induced endothelium-dependent inhibition and direct activation of plateletvessel wall interaction. Circulation 1994; 89: 2266-72.

[27] Lüscher TF, Diederich D, Siebenmann R et al. Difference between endothelium-dependent relaxation in arterial and in venous coronary bypass grafts. N Engl J Med 1988; 319: 462-7.

[28] Lüscher TF, Boulanger $\mathrm{CM}$, Dohi $\mathrm{Y}$, Yang $\mathrm{ZH}$. Endothelium-derived contracting factors. Hypertension 1992; 19: 117-30.

[29] Luscher TF, Yang Z, Tschudi $M$ et al. Interaction between endothelin-1 and endothelin-derived relaxing factor in human arteries and veins. Circ Res 1990; 66: 1088-94.

[30] Kasuya Y, Ishikawa T, Yanagisawa M, Kimura S, Goto K, Masaki T. Mechanism of contraction to endothelin in isolated porcine coronary artery. Am J Physiol, Heart Circ Physiol 1989; 257: H1828-35.

[31] Kasuya Y, Takuwa Y, Yanagisawa M, Kimura S, Goto K, Masaki T. Endothelin-1 induces vasoconstriction through two functionally distinct pathways in porcine coronary artery: contribution of phosphoinositide turnover. Biochem Biophys Res Commun 1989; 161: 1049-55.

[32] Boulanger C, Lüscher TF. Release of endothelin from the porcine aorta. Inhibition of endothelium-derived nitric oxide. J Clin Invest 1990; 85: 587-90.

[33] Kimura S, Kasuya Y, Sawamura T et al. Structure-activity relationships of endothelin: importance of the C-terminal moiety. Biochem Biophys Res Commun 1988; 156: 1182-6.

[34] Yanagisawa M, Kurihara H, Kimura S et al. A novel potent vasoconstrictor peptide produced by vascular endothelial cells. Nature 1988; 332: 411-5.

[35] Arai H, Hori S, Aramori I, Ohkubo H, Nakanishi S. Cloning and expression of a cDNA encoding an endothelin receptor. Nature 1990; 348: 730-2.

[36] Sakurai T. Yanagisawa M, Takuwa $Y$ et al. Cloning of a cDNA encoding a non-isopeptide-selective subtype of the endothelin receptor. Nature 1990;348:732-5.

[37] Simonson MS, Wann S, Mene P et al. Endothelin stimulates phospholıpase $\mathrm{C}, \mathrm{Na}+/ \mathrm{H}+$ exchange, $\mathrm{c}$-fos expression, and mitogenesis in rat mesangial cells. J Clin Invest 1989; 83: 708-12.

[38] Resink TJ, Scott-Burden T, Buhler FR. Endothelin stimulates phospholıpase $\mathrm{C}$ in cultured vascular smooth muscle cells. Biochem Biophys Res Commun 1988; 157: 1360-8.

[39] Wallnofer A, Weir S. Ruegg U. Cauvin C. The mechanism of action of endothelin-1 as compared with other agonists in vascular smooth muscle. J Cardiovasc Pharmacol 1989; 13 (Suppl 5): S23-31.

[40] Goto K, Kasuya Y, Matsuki $N$ et al. Endothelin activates the dihydropyridine-sensitive, voltage-dependent $\mathrm{Ca}(2+)$ channel in vascular smooth muscle. Proc Natl Acad Sci USA 1989; 86: 3915-18.

[41] Lüscher TF, Seo BG, Bühler FR. Potential role of endothelin in hypertension. Hypertension 1993; 21: 752-7.

[42] Wright CE, Fozard JR. Regional vasodilation is a prominent feature of the haemodynamic response to endothelin in anaesthetized, spontaneously hypertensive rats. Eur $\mathbf{J}$ Pharmacol 1988; 155: 201-3.

[43] Warner TD. de Nucci G, Vane JR. Rat endothelin is a vasodilator in the isolated perfused mesentery of the rat. Eur J Pharmacol 1989: 159: 325-6.

[44] Dohi Y. Lüscher TF. Endothelin in hypertensive resistance arteries. Intraluminal and extraluminal dysfunction. Hypertension 1991; 18: 543-9.

[45] Kiowski W, Lüscher TF, Linder L, Bühler FR. Endothelin1 -induced vasoconstriction in humans. Reversal by calcium channel blockade but not by nitrovasodilators or endothelium-derived relaxing factor. Circulation 1991; 83: 469-75.

[46] Goerre S. Wenk M, Bärtsch P et al. Endothelin-1 in pulmonary hypertension associated with high altitude. Circulation 1995; 90: 359-64.

[47] Rakugi $H$, Tabuchi $Y$, Nakamaru $M$ et al. Evidence for endothelin-1 release from resistance vessels of rats in response to hypoxia. Biochem Biophys Res Commun 1990: 169: 973-7.
[48] Dohi Y, Hahn AW, Boulanger CM, Bühler FR, Lüscher TF. Endothelin stimulated by angiotensin II augments contractility of spontaneously hypertensive rat resistance arteries. Hypertension 1992; 19: 131-7.

[49] Suzuki N, Matsumoto H, Kitada Cet al. Immunoreactive endothelin- 1 in plasma detected by a sandwich-type enzyme immunoassay. J Cardiovasc Pharmacol 1989: 13 (Suppl 5): 151-2.

[50] Wagner OF, Christ G, Wojta J et al. Polar secretion of endothelin-1 by cultured endothelial cells. J Biol Chem 1992; 267: 16066-8.

[51] Stewart DJ, Langleben D, Cernacek P, Cianflone K. Endothelin release is inhibited by coculture of endothelial cells with cells of vascular media. Am J Physiol 1990; 259: H1928-32.

[52] Yokokawa K, Kohno M, Yasunarı K, Murakawa K, Takeda T. Endothelin-3 regulates endothelin-1 production in cultured human endothelial cells. Hypertension 1991; 18: 304-15.

[53] Saijonmaa O, Ristimaki A, Fyhrquist F. Atrial natriuretic peptide, nitroglycerine, and nitroprusside reduce basal and stimulated endothelin production from cultured endothelial cells. Biochem Biophys Res Commun 1990; 173: 514-20.

[54] Boulanger CM, Lüscher TF. Hırudin and nitrates inhibit the thrombin-induced release of endothelin from the intact porcine aorta. Circ Res 1991; 68: 1768-72.

[55] Aramori I, Nirei H, Shoubo M et al. Subtype selectivity of a novel endothelin antagonist. FR139317, for the two endothelin receptors in transfected Chinese hamster ovary cells. Mol Pharmacol 1993; 43: 127-31.

[56] Cardell LO, Uddman R, Edvinsson L. A novel ETA receptor antagonist, FR139317, inhibits endothelin-induced contractions of guinea-pig pulmonary arteries, but not trachea. Br J Pharmacol 1993; 108: 448-52.

[57] Sogabe K, Nirei H, Shoubo M et al. Pharmacological profile of FR139317, a novel, potent endothelin ETA receptor antagonist. J Pharmacol Exp Ther 1993; 264: 1040-6.

[58] Eguchi S. Hirata $Y$, Ihara M, Yano M, Marumo F. A novel ETA antagonist (BQ-123) inhibits endothelin-1induced phosphoinositide breakdown and DNA synthesis in rat vascular smooth muscle cells. FEBS Lett 1992; 302: $243-6$.

[59] Fujimoto M, Mihara S, Nakajima S, Ueda M, Nakamura M, Sakurai K. A novel non-peptide endothelin antagonist isolated from bayberry, Myrica cerifera. FEBS Lett 1992; 305: 41-4.

[60] Hiley CR, Cowley DJ, Pelton, JT, Hargreaves AC. BQ-123, cyclo(-D-Trp-D-Asp-Pro-D-Val-Leu), is a non-competitive antagonist of the actions of endothelin-1 in SK-N-MC human neuroblastoma cells. Biochem Biophys Res Commun 1992: 184: 504-10.

[61] Ihara M, Noguchi K, Saeki T et al. Biological profiles of highly potent novel endothelin antagonists selective for the ETA receptor. Life Sci 1992; 50: 247-55.

[62] Ohlstein EH, Arleth A, Bryan H, Elliott JD, Sung CP. The selective endothelin receptor antagonist BQ-123 antagonizes endothelin-1-mediated mitogenesis. Eur J Pharmacol 1992: 225: 347-50.

[63] Samson WK. The endothelin-A receptor subtype transduces the effects of the endothelins in the anterior pituitary gland. Biochem Biophys Res Commun 1992; 187: $590-5$.

[64] Reily MD. Thanabal V, Omecinsky DO, Dunbar JJ, Doherty AM. DePue PL. The solution structure of a cyclic endothelin antagonist. BQ-123, based on $1 \mathrm{H}-1 \mathrm{H}$ and $13 \mathrm{C}-1 \mathrm{H}$ three bond coupling constants. FEBS Lett 1992; 300: 136-40.

[65] Takeda M, Breyer MD, Noland TD et al. Endothelin-1 receptor antagonist: effects on endothelin- and cyclosporine-treated mesangial cells. Kıdney Int 1992: 41 : 1713-9.

[66] Webb ML. Dickinson KE. Delaney CL et al. The endothelin receptor antagonist. BQ-123, inhibits angiotensin IIinduced contractions in rabbit aorta. Biochem Biophys Res Commun 1992; 185: 887-92. 
[67] Sun XY, Hedner T, Feng Q, Edvinsson L. Inhibition of endothelin (ET-1) induced pressor responses by the endothelin (ETA) receptor antagonist FR139317 in the pithed rat. Blood Pressure 1992: 1: 108-12.

[68] Clozel M. Watanabe H. BQ-123, a peptide endothelin ETA receptor antagonist, prevents the early cerebral vasospasm following subarachnoid haemorrhage after intracisternal but not intravenous injection. Life Sci 1993: 52: 825-34.

[69] Urade Y, Fujitani Y, Oda K, Watakabe T, Umemura I. Takai M, Okada T, Sakata K, Karaki H: An endothelin B receptorselective antagonist: IRL 1038, [Cys11-Cys15]-endothelin1(11-21). FEBS Lett 1992; 311: 12-6.

[70] Breu V, Loffler BM. Clozel M. In vitro characterization of Ro 46-2005, a novel synthetic non-peptide endothelin antagonist of ETA and ETB receptors. FEBS Lett 1993; 334: $210-4$.

[71] Ishida F, Saeki K, Saeki T et al. Suppressive effects of the endothelin receptor (ETA) antagonist BQ-123 on ET-1induced reduction of lipoprotein lipase activity in 3T3-L1 adipocytes. Biochem Pharmacol 1992; 44: 1431-6.

[72] Seo BG, Oemar BS, Siebenmann R, von Segesse L, Lüscher TF. Both ETA- and ETB-receptors mediate contractions to endothelin-1 in human blood vessels. Circulation 1994; 89 : $1203-8$.

[73] Wenzel RR, Noll G. Lüscher TF. Endothelin receptor antagonists inhibit endothelin in human skin microcirculation. Hypertension 1994; 23: 581-6.

[74] Warner TD, Allcock GH, Corder R, Vane JR. Use of the endothelin antagonists BQ-123 and PD142893 to reveal three endothelin receptors mediating smooth muscle contraction and the release of EDRF. Br J Pharmacol 1993; 110: 777-82.

[75] Lerman A, Click RL, Narr BJ et al. Elevation of plasma endothelın associated with systemic hypertension in humans following orthotopic liver transplantation. Transplantation 1991: 51: 646-50.

[76] Lerman A, Edwards BS, Hallet JW, Heublein DM, Sandberg SM, Burnett JJ. Circulating and tissue endothelin immunoreactivity in advanced atherosclerosis. $\mathrm{N}$ Engl $\mathrm{J}$ Med 1991; 325: 997-1001.

[77] Stewart DJ, Kubac G, Costello KB, Cernacek P. Increased plasma endothelin- 1 in the early hours of acute myocardial function. J Am Coll Cardiol 1991: 18: 38-43.

[78] Stewart DJ, Cernacek P, Costello KB, Rouleau JL. Elevated endothelin-1 in heart failure and loss of normal response to postural change. Circulation 1992; 85: 510-7.

[79] Stelzner TJ, O’Brien RF, Yanagisawa M et al. Increased lung endothelin-1 production in rats with idiopathic pulmonary hypertension. Am J Phys Lung Cell Mol Physiol 1992; 262: 6-5.

[80] Clozel M, Breu V, Burri K et al. Pathophysiological role of endothelin revealed by the first orally active endothelin receptor antagonist. Nature 1993; 365: 759-61.

[81] Galle J, Mulsch A, Busse R, Bassenge E. Effects of native and oxidized low density lipoproteins on formation and inactivation of endothelium-derived relaxing factor. Arterioscleros Thromb 1991; 11: 198-203.

[82] Simon BC, Cunningham LD, Cohen RA. Oxidized low density lipoproteins cause contraction and inhibit endotheliumdependent relaxation in the pig coronary artery. J Clin Invest 1990; 86: 75-9.

[83] Tanner FC, Noll G, Boulanger CM. Lüscher TF. Oxidized low density lipoproteins inhibit relaxations of porcine coronary arteries. Role of scavenger receptor and endotheliumderived nitric oxide [see comments]. Circulation 1991; 83: 2012-20.

[84] Minor R Jr., Myers PR, Guerra R Jr., Bates JN. Harrison DG. Diet-induced atherosclerosis increases the release of nitrogen oxides from rabbit aorta. J Clin Invest 1990; 86: 2109-16.

[85] Yla-Herttuala S, Palinski W, Rosenfeld ME et al. Evidence for the presence of oxidatively modified low density lipoprotein in atherosclerotic lesions of rabbit and man. $\mathbf{J}$ Clin Invest 1989; 84: 1086-95.

[86] Sparrow CP, Doebber TW, Olszewski J et al. Low density lipoprotein is protected from oxidation and the progression of atherosclerosis is slowed in cholesterol-fed rabbits by the antioxidant $\mathrm{N}, \mathrm{N}^{\prime}$-diphenyl-phenylenediamine. J Clin Invest 1992; 89: 1885-91.

[87] Maxwell SR: Can anti-oxidants prevent ischaemic heart disease? J Clin Pharm Ther 1993: 18: 85-95.

[88] Mao SJ, Yates MT, Rechtin AE. Jackson RL, Van Sickle WA. Antioxidant activity of probucol and is analogues in hypercholesterolemic Watanabe rabbits. J Med Chem 1991; 34: 298-302.

[89] Mantha SV, Prasad M, Kalra J, Prasad K. Antioxidant enzymes in hypercholesterolemia and effects of vitamin $E$ in rabbits. Atherosclerosis 1993; 101: 135-44.

[90] Kita T, Ishii K, Yokode M et al. The role of oxidized low density lipoprotein in the pathogenesis of atherosclerosis. Eur Heart J 1990; 11: 122-7.

[91] Jialal I. Norkus EP, Cristol L, Grundy SM. Beta-Carotene inhibits the oxıdative modification of low-density lipoprotein. Biochim Biophys Acta 1991; 1086: 134-8.

[92] Ferns GA, Konneh M, Anggard EE. Vitamin E: the evidence for an anti-atherogenic role. Artery 1993; 20: 61-94.

[93] Shimokawa H, Vanhoutte PM. Impaired endothelium dependent relaxation to aggregating platelets and related vasoactive substances in porcine coronary arteries in hypercholesterolemia and atherosclerosis. Circ Res 1989; 64: 900-14.

[94] Bossaller C, Habib GB, Yamamoto H, Willaams C, Wells S, Henry PD: Impaired muscarinic endothelium-dependent relaxation and cyclic guanosine 5 '-monophosphate formation in atherosclerotic human coronary artery and rabbit aorta. J Clin Invest 1987; 79: 170-4.

[95] Zeiher AM, Drexler H, Saurbier B, Just H. Endotheliummediated coronary blood flow modulation in humans. Effects of age, atherosclerosis, hypercholesterolemia, and hypertension. J Clin Invest 1993; 92: 652-62.

[96] Gage JE, Hess OM, Murakamı T, Ritter M, Grimm J, Krayenbuehl HP. Vasoconstriction of stenotic coronary arteries during dynamic exercise in patients with classic angina pectoris: reversibility by nitroglycerin. Circulation 1986; 73: 865-76.

[97] Shimokawa H, Aarhus LL, Vanhoutte PM. Porcine coronary arteries with regenerated endothelium have a reduced endothelium-dependent responsiveness to aggregating platelets and serotonin. Circ Res 1987; 61: 256-70.

[98] Miyauchi T, Yanagisawa M, Tomizawa T et al. Increased plasma concentrations of endothelin- 1 and big endothelin-1 in acute myocardial infarction [letter]. Lancet 1989:2: 53-4.

[99] Boulanger CM, Tanner FC. Bea ML, Hahn AW, Werner A, Lüscher TF. Oxidized low density lipoproteins induce mRNA expression and release of endothelin from human and porcine endothelium. Circ Res 1992; 70: 1191-7.

[100] Hirata Y, Takagi Y, Fukuda Y, Marumo F. Endothelin is a potent mitogen for rat vascular smooth muscle cells. Atherosclerosis 1989; 78: 225-8.

[101] Dubey RK, Ganten D, Lüscher TF. Enhanced migration of smooth muscle cells from Ren-2 transgenic rats in response to angiotensin II: Inhibition by nitric oxide (Abstract). Hypertension 1993; 22: 412.

[102] Garg UC, Hassid A. Nitric oxide-generating vasodilators and 8-bromo-cyclic guanosine monophosphate inhibit mitogenesis and proliferation of cultured rat vascular smooth muscle cells. J Clin Invest 1989; 83: 1774-7.

[103] Lüscher TF, Tanner FC. Endothelial regulation of vascular tone and growth. Am J Hypertension 1993; 6: S283-S293.

[104] Dohi Y, Criscione L, Pfeiffer M, Lüscher TF. Angiotensin blockade or calcium antagonists improve endothelial dysfunction in hypertension: studies in perfused mesenteric resistance arteries. J Cardiovasc Pharmacol 1994; 24: $372-9$.

[105] Lüscher TF, Vanhoutte PM. Endothelium-dependent contractions to acetylcholine in the aorta of the spontaneously hypertensive rat. Hypertension 1986; 8: 344-8. 
[106] Tschudi MA, Noll G, Arnet UA, Novosel D, Ganten D, Lüscher TF. Alterations of vascular function in coronary arteries of ren-2 transgenic rats. Circulation 1994; 89: 2780-6.

[107] Lüscher TF, Raij L, Vanhoutte PM. Endothelium-dependent vascular responses in normotensive and hypertensive Dahl rats. Hypertension 1987; 9: 157-63.

[108] Nava E, Lüscher TF. Increased activity of nitric-oxide synthase in the aorta of spontaneously hypertensive rats (Abstract). Eur J Clin Invest 1994.

[109] Panza JA, Quyyumi AA, Callahan TS, Epstein SE. Effect of antihypertensive treatment on endothelium-dependent vascular relaxation in patients with essential hypertension. $\mathrm{J}$ Am Coll Cardiol 1993; $21: 1145-51$.

[110] Panza JA, Casino PR, Badar DM, Quyyumi AA: Effect of increased availability of endothelium-derived nitric oxide precursor on endothelium-dependent vascular relaxation in normal subjects and in patients with essential hypertension [see comments]. Circulation 1993; 87: 1475-81.

[111] Panza JA, Quyyumi AA, Brush JJ, Epstein SE. Abnormal endothelium-dependent vascular relaxation in patients with essential hypertension [see comments]. N Engl J Med 1990; 323: $22-7$.

[112] Taddei S, Virdis A, Mattei P, Salvetti A. Vasodilation to acetylcholine in primary and secondary forms of human hypertension. Hypertension 1993; 21: 929-33.
[113] Cockcroft JR, Chowiencyzk PJ, Benjamin N, Ritter JM. Preserved endothelium-dependent vasodilation in patients with essential hypertension. N Engl J Med 1994; 330: $1036-40$.

[114] Treasure CB, Manoukian SV, Klein JL et al. Epicardial coronary artery responses to acetylcholine are impaired in hypertensive patients. Circ Res 1992; 71: 776-81.

[115] Treasure CB, Klein JL, Vita JA et al. Hypertension and left ventricular hypertrophy are associated with impaired endothelium-mediated relaxation in human coronary resistance vessels. Circulation 1993; 87: 86-93.

[116] McMahon EG, Palomo MA, Moore, WM, McDonald JF, Stern MK. Phosphoramidon blocks the pressor activity of porcine big endothelin-1-(1-39) in vivo and conversion of big endothelin-1-(1-39) to endothelin-1-(1-21) in vitro. Proc Natl Acad Sci USA 1991; 88: 703-7.

[117] Nishikibe $M$, Tsuchida S, Okada $M$ et al. Antihypertensive effect of a newly synthesized endothelin antagonist, BQ-123, in a genetic hypertensive model. Life Sci 1993; 52: 717-24.

[118] Paul, Ganten D. Endothelin-2-gene transgenic rats. 1994. (personal communication).

[119] Kurihara Y, Kurihara H, Suzuki H et al. Elevated blood pressure and craniofacial abnormalities in mice deficient in endothelin-1. Nature 1994; 368: 703-10.

[120] Lüscher TF: Do we need endothelin antagonists? Cardiovasc Res 1993; 27: 2089-93. 